\title{
Usability, from a Bigger Picture
}

\author{
Mercedes Sanchez and José Luis Adán Gil \\ Mercedes Sanchez Usabilidade, R. Alfenas, 56 - Granja Viana, CEP 06351-165 \\ Carapicuiba/SP, Brasil \\ falecomemercedessanchez.com.br
}

\begin{abstract}
This paper presents the strategy of Mercedes Sanchez Usabilidade, a Brazilian consultancy firm, to spread the usability concept among consumers and companies in a way that no other company has ever done in Brazil. The strategy made usability news in the media and it is benefiting consumers, companies and professionals of user experience all over the country.
\end{abstract}

Keywords: usability, communication strategy, blog, Brazil.

\section{Introduction}

The usability concept is not familiar to Brazilians, as well as inside the companies. Many consumers tend to think it is their fault if they cannot use something, especially if it is related to computers and technology. They blame neither the product nor the company, instead they feel guilty. So, if consumer does not complain about designs that are not friendly, why would the companies worry about it?

In view of this fact, the Brazilian consultancy firm Mercedes Sanchez Usabilidade decided to focus on an extensive action of making usability known. The objective was to bring the concept closer to the daily reality of consumers and companies.

The strategy was to create and bring out a way for people to express themselves about products, services and sites that are not user friendly and, therefore, catch the attention of the companies. The blog Tá Difícil ("This is difficult") was put together for this purpose.

Mercedes Sanchez Usabilidade has been offering services related to User Experience since 2003 and is partner with usability companies from Europe and USA, conducting usability studies on web sites and mobile phones in Brazil, as part of global studies.

\section{Sowing the Seeds}

Mercedes Sanchez Usabilidade took the 2006 World Usability Day challenge seriously - by disclosing the usability concept and by encouraging people to protest against things that are difficult to use - and on November $14^{\text {th }}, 2006$ the blog "Tá Dificil" ("This is difficult") - www.tadificil.com.br - was launched, inspired by the American website "This is Broken". 
"Tá Difícil..." became a discussion forum for consumers who face difficulties in using, from sites, systems and electronic products up to the doors and faucets. It is entirely fed by the users, who send pictures, texts and videos. By disclosing a problem, this generates comments of others who have already had the same or a similar problem. Little by little, it shows the consumers that if there is something that is difficult to use, it is not their fault and that they should complain about it.

There are some dramatic posts, such as the one from a 59-year-old gentleman who purchased a DVD recorder to "convert my tapes from VHS to DVD, so that my grandchildren could know a little bit about my life story" and who could not record anything because of difficulties in understanding how the gadget works. Another consumer spent 2 years fighting with an electronic dictionary, whose installation program leads the user to an error and requires that the installation $\mathrm{CD}$ be inserted every time the dictionary is used.

There are also posts from telecommunication company clients who feel outraged for being forced to navigate through the depths of the sites just to find a telephone number or an e-mail address.

\section{The First Harvests}

These and other stories, enriched with comments and tips from the readers of the blog, caught the eye of the media. The Usability subject, not only the blog, made the news on major Brazilian TV networks, radio stations, newspapers and magazines.

The companies started reacting in a very positive and even surprising manner at times, such as Philips Brasil, who added a link to "Tá Difícil" to the company's blog called "SimplesCidade". Tales Rocha, Philips' Internet manager, said "Tá Difícil is complementary to the company's blog and it is worth recommending it."

The difficulties to access the online help reported by users of Submarino, a big e-commerce site, were dealt with by the company and this was communicated by the blog. The same happened with Banco Santander, who anticipated an improvement on the internet-banking menu, based on a complaint posted on Tá Difícil.

\section{Conclusion}

The usability concept is becoming closer to those thousands of users who have accessed the blog, those millions of people who watched it on TV, as well as those companies who are positioning themselves and are promoting improvements in their sites and products.

Mercedes Sanchez Usabilidade, through Tá Difícil, are doing their part in bringing about the Usability concept and in making people and companies aware of the need of making this world an easier place to live in. 